\title{
Microsatellite DNA marker inheritance indicates preferential pairing between two highly homologous genomes in polyploid and hemisexual dog-roses, Rosa L. Sect. Caninae DC.
}

\author{
H Nybom ${ }^{1}$, GD Esselink², G Werlemark ${ }^{1}$ and B Vosman ${ }^{2}$ \\ ${ }^{1}$ Balsgård-Department of Crop Science, Swedish University of Agricultural Sciences, Fjälkestadsvägen 459, 291 94 Kristianstad, Sweden; \\ ${ }^{2}$ Department of Biodiversity and Breeding, Plant Research International, PO Box 16, 6700 AA Wageningen, The Netherlands
}

\begin{abstract}
According to previous cytological evidence, the hemisexual dog-rose species, Rosa sect. Caninae, transmit only seven chromosomes (derived from seven bivalents) through their pollen grains, whereas egg cells contain 21,28 or 35 chromosomes (derived from seven bivalents and 14, 21 or 28 univalents) depending on ploidy level. Two sets of reciprocal pairwise interspecific crosses involving the pentaploid species pair $R$. dumalis and $R$. rubiginosa, and the pentaploid/tetraploid species pair $R$. sherardii and $R$. villosa, were analysed for 13 and 12 microsatellite DNA loci, respectively. Single loci were represented by a maximum of three simultaneously occurring alleles in $R$. villosa, and four alleles in the other three parental plants. In the experimentally derived offspring, the theoretical maximum of five alleles was found for only one locus in the pentaploid progenies. Microsatellite DNA allele composition was identical with that of the maternal parent in 10 offspring plants, which were probably derived through apomixis. Almost all microsatellite DNA alleles were shared with the maternal
\end{abstract}

parent also in the remaining offspring, but 1-4 alleles shared only with the paternal parent, indicating sexual seed formation. Analysis of quantitative peak differences allowed a tentative estimation of allelic configuration in the individual plants, and suggested that bivalent formation preferentially takes place between chromosomes that consistently share the same microsatellite alleles and therefore appear to be highly homologous. Moreover, alleles that were shared between the species in each cross combination comparatively often appear to reside on the bivalent-forming chromosomes, whereas species-specific alleles instead occur comparatively often on the univalent-forming chromosomes and are therefore inherited through the maternal parent only. Recombination then takes place between very similar genomes also in interspecific crosses, resulting in a reproduction system that is essentially a mixture between apomixis and selfing.

Heredity (2004) 92, 139-150, advance online publication, 17 December 2003; doi:10.1038/sj.hdy.6800332

Keywords: apomixis; heterogamy; interspecific hybridization; microsatellite DNA; polyploidy; Rosa sect. Caninae

\section{Introduction}

The dog-roses, Rosa L. sect. Caninae DC., constitute a well-defined group of 20-30 species occurring mainly in Europe but also in North Africa and northwestern Asia (Zielinski, 1985). All species in this section are polyploid $(x=7)$ and have the peculiar canina meiosis described 80 years ago (Täckholm, 1920, 1922; Blackburn and HeslopHarrison, 1921). Pentaploids are most common, but tetraploids, as well as hexaploids, have also been reported (Nilsson, 1967; Klasterska and Klastersky, 1974). Regardless of chromosome number, only seven bivalents are formed and the remaining chromosomes occur as univalents. The univalents are not included in viable pollen, which therefore contain only seven chromosomes. In contrast, all the univalents are included

Correspondence: H Nybom, Balsgård-Department of Crop Science, Swedish University of Agricultural Sciences, Fjälkestadsvägen 459, 291 94 Kristianstad, Sweden.E-mail: Hilde.Nybom@vv.slu.se

Received 15 February 2003; accepted 25 March 2003 in viable egg cells, which instead contain 21, 28 or 35 chromosomes.

Species with canina meiosis have been termed hemisexual, since only seven chromosomes are inherited from the pollen parent as compared to 21,28 or 35 from the seed parent. As expected, matroclinal inheritance (offspring very similar to seed parent) for various morphological traits has been described in progenies derived from interspecific crosses (Gustafsson, 1944; Kroon and Zeilinga, 1974; Werlemark et al, 1999; Werlemark and Nybom, 2001). However, matroclinal inheritance may also stem from apomixis, which has been reported to occur occasionally in some dog-rose species (Gustafsson, 1944; Kroon and Zeilinga, 1974; Wisseman and Hellwig, 1997; Werlemark, 2000).

Recently, molecular markers have been applied to studies of the effects of canina meiosis. Analysis of progenies from interspecific cross-pollinations using random-amplified polymorphic DNA (RAPD) demonstrated that almost all of the seed parent-specific markers are distributed to each and all of the seedlings (Werlemark et al, 1999; Werlemark, 2000; Werlemark and 
Nybom, 2001). By contrast, each seedling usually inherits only about half (or sligthly less) of the pollen parentspecific markers, approximately $35-40 \%$ of the pollenspecific markers have not been found in any of the offspring, and may never take part in the bivalent formation.

Whereas RAPDs are relatively cheap and easy to use, they have experimental drawbacks (Jones et al, 1997). Moreover, individual bands are usually scored only as present or absent, thereby treating these characters as dominantly inherited. Consequently, RAPDs are not sufficiently informative for in-depth analysis of chromosomal distribution. By contrast, PCR-amplified sequencetagged microsatellite sites (STMS) are codominantly inherited, and often detect numerous alleles at each individual locus. Lately, several microsatellite DNA studies have demonstrated high levels of marker heterozygosity in the family Rosaceae (Guilford et al, 1997; Hokanson et al, 1998; Sosinski et al, 2000; Esselink et al, 2003).

The present study was conducted to: (1) determine whether microsatellite DNA loci primer pairs, previously isolated from $R$. hybrida genomic DNA (Esselink et al, 2003) would be able to detect multiple, polymorphic alleles in four dog-rose species and (2) analyse some dogrose progenies obtained by interspecific cross-pollinations between four dog-rose species in order to further elucidate chromosomal inheritance.

\section{Materials and methods}

\section{Plant material}

Four plants, collected in the wild and subsequently grown at Balsgård, S. Sweden, were initially analysed for microsatellite polymorphism at 22 loci. These plants represented one species each: $R$. dumalis Bechst. subsp. dumalis (Tjörnedala, Province of Skåne), $R$. rubiginosa L. (Fjälkestad, Province of Skåne), R. sherardii Davies var. venusta (Scheutz) Herring (Falkenberg, Province of Halland) and $R$. villosa L. subsp. mollis (Sm.) Keller (Tjörnedala, Province of Skåne). Of these species, $R$. villosa is reported to be tetraploid and $R$. dumalis and R. rubiginosa pentaploid (Nilsson, 1967). For $R$. sherardii, tetraploids, pentaploids and hexaploids have been reported.

In addition, 36 seedlings, derived from experimental cross-pollinations, were analysed for microsatellite alleles at 13 or 12 loci. Of these seedlings, 10 had been obtained from pollinating $R$. dumalis with $R$. rubiginosa, and 10 from the reciprocal cross. Previous investigations using RAPD and pollen stainability (Werlemark, 2000), indicated that five and four plants, respectively, in these two cross combinations were derived through apomixis.

Another 10 seedlings were obtained from pollinating $R$. sherardii with $R$. villosa, and the remaining six seedlings were obtained from the reciprocal cross. According to previous RAPD analyses, all seedlings in the $R$. sherardii $\times R$. villosa cross were sexually derived, whereas one seedling in the reciprocal cross seemed to be apomictically derived (Werlemark and Nybom, 2001).

\section{Ploidy estimation}

Leaf material of the four parental plants, and all of the offspring plants, except five that had died since the DNA analyses, was subjected to flow cytometry analysis (Plant Cytometry Services) to determine ploidy level.

\section{Microsatellite DNA analyses}

Leaf material was collected and stored at $-80^{\circ} \mathrm{C}$ until used for DNA extraction according to Holm (1995). The STMS amplifications were performed in $20 \mu \mathrm{l}$ reactions containing $16 \mathrm{ng}$ genomic DNA, 4 pmol of each primer, $100 \mathrm{mM}$ of each dNTP, $10 \mathrm{mM}$ Tris- $\mathrm{HCl}$ (pH 9.0), $20 \mathrm{mM}$ $\left(\mathrm{NH}_{4}\right)_{2} \mathrm{SO}_{4}, 0.01 \%$ Tween $20,1.5 \mathrm{mM} \mathrm{MgCl} 2$ and $0.2 \mathrm{U}$ Goldstar Taq DNA polymerase (Eurogentec). Amplifications were run on an MJ PTC-200. The PCR program consisted of an initial denaturation step at $94^{\circ} \mathrm{C}$ for $3 \mathrm{~min}$, followed by 30 cycles of $94^{\circ} \mathrm{C}$ for $30 \mathrm{~s} ; 50$ or $55^{\circ} \mathrm{C}$ for $30 \mathrm{~s}$ and $72^{\circ} \mathrm{C}$ for $60 \mathrm{~s}$; and a final extension at $72^{\circ} \mathrm{C}$ for $3 \mathrm{~min}$. Unlabelled primers were obtained from Isogen, and fluorescently labelled primers from Amersham/Pharmacia (Cy5) and Applied Biosystems (HEX, NED, 6-FAM). Fluorescent $\mathrm{Cy} 5$ amplification products were detected using an ALFexpress DNA sequencer (Amersham/ Pharmacia). A volume of $5 \mu \mathrm{l}$ of the amplification product was mixed with $5 \mu \mathrm{l}$ of formamide loading buffer, containing Cy5 sizers of 78 and $323 \mathrm{bp}$. After denaturation at $90^{\circ} \mathrm{C}$ for $3 \mathrm{~min}$, followed by quenching on ice, $5 \mu \mathrm{l}$ samples were loaded onto a standard sequencing gel (GibcoBRL sequencing mix; 6\% polyacrylamide, $7 \mathrm{M}$ urea, $1 \times$ TBE, Life Technologies). Gels were run for $6 \mathrm{~h}$ at a constant power $(25 \mathrm{~W})$ at $55^{\circ} \mathrm{C}$. Fragment sizes were determined automatically using Pharmacia Fragment Manager software. Fluorescent HEX, NED and FAM amplification products were detected using an ABI Prism 3700 DNA Analyzer (Perkin-Elmer Biosystems). Amplification products of three different dyes were pooled and purified using Multiscreen 96-well Sephadex G50 filtration plates (Millipore). A volume of $1 \mu \mathrm{l}$ of purified sample was mixed with $10 \mu \mathrm{l}$ of formamide loading buffer containing a ROX-labelled internal lane standard (70-400 bp). After denaturation at $95^{\circ} \mathrm{C}$ for $5 \mathrm{~min}$, followed by quenching on ice, $1 \mu \mathrm{l}$ samples were loaded in a capillary (3700 POP6, Perkin-Elmer Biosystems) and run for $1.5 \mathrm{~h}$. Fragment sizes were determined automatically using Genescan Analysis Software (Release 1.1 3700 software Perkin-Elmer Biosystems). All samples were genotyped in accordance with reference alleles [as described in Esselink et al (2003)] using Genotyper Software (version 3.5 NT, Perkin-Elmer Biosystems).

\section{Results}

\section{Ploidy levels}

Of the parental species, $R$. dumalis, $R$. sherardii and $R$. rubiginosa proved to be pentaploid and $R$. villosa was tetraploid. All 20 offspring in the crosses between $R$. dumalis and R. rubiginosa were also checked. Of these, 19 were pentaploid as expected. One plant, $S_{40}$ with $R$. rubiginosa as the maternal parent, was chimaeric and had diploid, as well as pentaploid, nuclei. All 10 plants in the $R$. sherardii $\times R$. villosa cross were pentaploid, whereas the only plant checked in the reciprocal cross was tetraploid. Apart from the deviating $S_{40}$, all the plants appeared to have the same chromosome number as the maternal parent, in accordance with the expectations for the canina meiosis. 


\section{Screening of parental plants}

The four parental rose plants were each analysed for 22 microsatellite loci, which represent at least six linkage groups in the rose genome (Table 1). All but two (found in $R$. rubiginosa) of these alleles were previously detected in a set of 30 rootstock varieties (including $R$. canina, $R$. chinensis, $R$. indica, $R$. multiflora, $R$. rubiginosa and $R$. rubrifolia) and 46 hybrid tea rose varieties (R. hybrida) (Esselink et al, 2003).

Only six loci lacked polymorphic alleles in both the $R$. dumalis $\times R$. rubiniginosa and $R$. sherardii $\times R$. villosa combinations. The remaining 16 loci could differentiate between at least one pair of parental plants, and 11 of them could differentiate between the two plants in both the pairs (Table 2). However, allelic configuration at locus AB40 proved difficult to interpret, due to the small size differences between alleles and it was therefore omitted from the study.

The number of alleles per locus could theoretically reach five in the three pentaploid parental plants, $R$. dumalis, $R$. sherardii and R. rubiginosa, and four in the tetraploid, $R$. villosa. No loci were found with five alleles in the parental plants. $R$. dumalis had nine loci with four alleles, and $R$. sherardii and $R$. rubiginosa each had five loci with four alleles. Similarly, there were seven loci with three alleles in $R$. villosa, but none with four alleles.

Counted across all 15 investigated loci, a total of 48 alleles were found in $R$. dumalis, 47 alleles in R. sherardii, 42 alleles in $R$. rubiginosa and 36 alleles in $R$. villosa.

Table 1 Chromosomal location of microsatellite DNA marker loci and the number of alleles found in a screening material consisting of 30 rootstock varieties (representing various species) and $46 R$. hybrida varieties (Debener et al, 2001; Esselink et al, 2003) and in four dog-rose species

\begin{tabular}{lllll}
\hline Locus & $\begin{array}{l}\text { Linkage } \\
\text { group }\end{array}$ & $\begin{array}{l}\text { No. of alleles } \\
\text { in rootstocks } \\
\text { and R. hybrida }\end{array}$ & in Sect. & Polymorphism \\
\cline { 3 - 5 } & & & $D \times R$ & $S \times V$
\end{tabular}

\begin{tabular}{llrrll} 
RhAB1 & ND & 7 & 2 & No & No \\
RhAB13 & 4 & 13 & 5 & Yes & Yes \\
RhAB15 & 2 & 17 & 6 & Yes & Yes \\
RhAB22 & 6 & 12 & 3 & Yes & Yes \\
RhAB26 & ND & 17 & 6 & Yes & Yes \\
RhAB40 & 4 & 16 & $>4$ & Yes & Yes \\
RhB303 & ND & 9 & 5 & Yes & Yes \\
RhBK4 & ND & 8 & 1 & No & No \\
RhD201 & ND & 14 & 7 & Yes & Yes \\
RhD206 & 2 & 18 & 7 & Yes & Yes \\
RhD221 & 4 & 8 & 3 & No & Yes \\
RhE2b & ND & 10 & 5 & Yes & Yes \\
RhE3 & ND & 9 & 1 & No & No \\
RhEO506 & 2 & 18 & 7 & Yes & Yes \\
RhI402 & 3 & 7 & 2 & No & No \\
RhJ404 & 4 & 7 & 2 & Yes & No \\
RhM405 & ND & 4 & 2 & No & Yes \\
RhO517 & 1 & 5 & 3 & No & No \\
RhP507 & 4 & 18 & 4 & Yes & No \\
RhP518 & 5 & 7 & 4 & Yes & Yes \\
RhP519 & ND & 10 & 4 & Yes & No \\
RhP524 & ND & 11 & 2 & No & No \\
\hline
\end{tabular}

$\mathrm{ND}=$ not determined. Polymorphism in the investigated crosses, $R$. dumalis $\times R$. rubiginosa and its reciprocal $(\mathrm{D} \times \mathrm{R})$ and $R$. sherardii $\times R$. villosa and its reciprocal $(\mathrm{S} \times \mathrm{V})$, is indicated.
Corresponding ratios between the number of alleles found and number of theoretically possible alleles were $0.64,0.63,0.56$ and 0.60 for the four parental plants, indicating similar levels of heterozygosity. One case of almost total allele additivity was revealed; the $R$. sherardii plant shared 38 alleles with $R$. dumalis and 34 with $R$. villosa, in addition to which it had only two alleles not found in any of these other two species. Some of the shared alleles occurred in all three taxa.

\section{Screening of seedlings}

Two loci, RhD221 and RhM405, were informative only for offspring produced from the $R$. sherardii $\times R$. villosa cross and its reciprocal (Table 2). Similarly, the loci RhJ404, RhP507 and RhP519 were informative only for offspring obtained in the crosses involving $R$. dumalis and $R$. rubiginosa. The remaining 10 loci were used for analysis of all four progeny groups. The theoretical maximum of five alleles was reached for only one locus (RhEO506); in the pentaploid offspring obtained in crosses between $R$. dumalis and $R$. rubiginosa. For the pentaploid offspring in the $R$. sherardii $\times R$. villosa cross, a maximum of four alleles was found, and for the tetraploid offspring in the $R$. villos $a \times R$. sherardii cross, a maximum of three alleles.

All microsatellite DNA alleles occurring in the maternal parent were found also in all the offspring plants. By contrast, only six pollen parent-specific alleles were transmitted to the offspring. Counted across all studied loci, all of the seedlings obtained from the $R$. dumalis $\times R$. rubiginosa cross exhibited 23 alleles that were shared between the parents, and 20 that were seed parent-specific. In addition, one pollen parent-specific allele was found in some seedlings (see next section). In addition to the 23 shared alleles, the seedlings obtained from the $R$. rubiginosa $\times R$. dumalis cross had 14 seed parent-specific alleles and four pollen parent-specific alleles. Seedlings from the $R$. sherardii $\times R$. villosa cross exhibited 27 alleles that were shared between the parents, 11 seed parent-specific alleles and no pollen parent-specific alleles at all. Seedlings from the reciprocal cross had only one seed parent-specific allele and one pollen parent-specific, in addition to the 27 shared alleles.

\section{Apomixis vs sexuality}

In the $R$. dumalis $\times R$. rubiginosa cross, two offspring groups with five plants each had been specifically sampled for the present investigation according to previous analyses of RAPD variation and pollen viability (Werlemark, 2000). All 10 plants exhibited the same set of microsatellite alleles as the seed parent $R$. dumalis, except for one locus, RhEO506 (Figure 1). The five offspring that had previously been identified as resulting from sexual seed formation had one apparently paternally derived allele $(J)$, in addition to two alleles $(D, P)$ that were shared between the two parental plants, and two alleles (I, O) that were unique to the maternal parent, thus having the maximum number of five different alleles expected in a pentaploid (DIJOP). By contrast, the remaining five offspring were identical to the maternal parent also at this locus, in accordance with their putatively apomictic origin. The occurrence of only four RhEO506 alleles in $R$. dumalis and the five apomictically derived offspring 
Table 2 Allele distribution of microsatellite DNA markers in four parental dog-rose plants and in progeny groups resulting from interspecific pollination

\begin{tabular}{|c|c|c|c|c|c|c|c|c|c|}
\hline Plant material & $\begin{array}{l}\text { No. of } \\
\text { plants }\end{array}$ & RhAB13 & $R h A B 15$ & RhAB22 & $R h A B 26$ & $R h B 303$ & $R h D 201$ & $R h D 206$ & \\
\hline R. dumalis & 1 & BCEI & ELM & G & $\mathrm{GG}_{1}^{*} \mathrm{~L}$ & $\mathrm{ABDF}$ & EFHJ & CKOP & \\
\hline R. rubiginosa & 1 & BCEG & DEN & GI & AEGL & & AEHM & EIP & \\
\hline R. dumalis $\times R$. rubiginosa, $A^{*}$ & 5 & BCEI & ELM & $\mathrm{G}$ & $\mathrm{GG}_{1} \mathrm{~L}$ & $\mathrm{ABDF}$ & EFHJ & CKOP & \\
\hline$R$. dumalis $\times R$. rubiginosa, $S^{*}$ & 5 & BCEI & ELM & $\mathrm{G}$ & $\mathrm{GG}_{1} \mathrm{~L}$ & ABDF & EFHJ & CKOP & \\
\hline R. rubiginosa $\times R$. dumalis, $A^{*}$ & 4 & BCEG & DEN & GI & AEGL & $\mathrm{BD}$ & AEHM & EIP & \\
\hline R. rubiginosa $\times R$. dumalis, $S^{*}$ & 6 & BCEG & DEN & GI & AEGL & $\mathrm{BD}$ & AEHM & EIOP & \\
\hline R. sherardii & 1 & BCEI & DFM & GH & CGL & $\mathrm{ABDE}$ & EHK & CKOQ & \\
\hline R. villosa & 1 & BEI & DF & $\mathrm{H}$ & CG & BDE & $\mathrm{EH}$ & COO & \\
\hline R. sherardii $\times R$. villosa, $S^{*}$ & 10 & BCEI & DFM & GH & CGL & ABDE & EHK & CKOQ & \\
\hline R. villosa $\times R$. sherardii, $A^{*}$ & 1 & BEI & $\mathrm{DF}$ & $\mathrm{H}$ & CG & BDE & $\mathrm{EH}$ & COQ & \\
\hline R. villosa $\times R$. sherardii, $S^{*}$ & 5 & BEI & $\mathrm{DF}$ & $\mathrm{H}$ & CG & $\mathrm{BDE}$ & $\mathrm{EH}$ & COQ & \\
\hline Plant material & $\begin{array}{l}\text { No. of } \\
\text { plants }\end{array}$ & $\operatorname{RgD} 221$ & $R h E 2 b$ & RhEO506 & RhJ404 & RhM405 & $R h P 507$ & RhP518 & RhP519 \\
\hline R. dumalis & 1 & BCG & BCEI & DIOP & B & $\mathrm{AB}$ & AGI & BCDF & CFGJ \\
\hline R. rubiginosa & 1 & BCG & BCFI & DJMP & BG & $\mathrm{AB}$ & A & $\mathrm{BC}$ & FG \\
\hline R. dumalis $\times R$. rubiginosa, $A^{*}$ & 5 & ND & BCEI & DIOP & $\mathrm{B}$ & ND & AGI & BCDF & CFGJ \\
\hline$R$. dumalis $\times R$. rubiginosa, $S^{*}$ & 5 & ND & BCEI & DIJOP & $\mathrm{B}$ & ND & AGI & BCDF & CFGJ \\
\hline R. rubiginosa $\times R$. dumalis, $A^{*}$ & 4 & ND & $\mathrm{BCFI}$ & DJMP & BG & ND & A & $\mathrm{BC}$ & FG \\
\hline R. rubiginosa $\times R$. dumalis, $S^{*}$ & 6 & ND & BCFI & DIJMP & BG & ND & $\mathrm{A} G$ & $\mathrm{BC}$ & CFG \\
\hline R. sherardii & 1 & BCG & BCEI & DINP & $\mathrm{B}$ & $\mathrm{AB}$ & $\mathrm{AE}$ & BCDF & FGJ \\
\hline R. villosa & 1 & $\mathrm{BC}$ & $\mathrm{BCE}$ & DIO & $\mathrm{B}$ & A & $\mathrm{AE}$ & $\mathrm{CDF}$ & FGI \\
\hline$R$. sherardii $\times R$. villosa, $S^{*}$ & 10 & BCG & BCEI & DINP & ND & $\mathrm{AB}$ & ND & $\mathbf{B C D F}$ & ND \\
\hline$R$. villos $a \times R$. sherardii, $A^{*}$ & 1 & $\mathrm{BC}$ & $\mathrm{BCE}$ & DIO & ND & $\mathrm{A}$ & ND & $\mathrm{CDF}$ & ND \\
\hline R. villosa $\times R$. sherardii, $S^{*}$ & 5 & $\mathrm{BC}$ & $\mathrm{BCE}$ & DIO & ND & $\mathrm{A} B$ & ND & $\mathrm{CDF}$ & ND \\
\hline
\end{tabular}

$\mathrm{ND}=$ not determined. $\mathrm{A}^{*}=$ plants possibly derived through apomixis, according to previous RAPD data (Werlemark, 2000). $\mathrm{S}^{*}=$ plants derived through sexual seed set, according to previous RAPD data (Werlemark, 2000). $\mathrm{G}_{1}{ }^{*}=$ this allele is clearly different from the previously denoted G-allele, but differs by only one basepair. Alleles that are unique for one of the parents in each cross combination are given in bold. Alleles in the offspring that must have been inherited from the paternal parent are given in italics.

suggests that one of these alleles occurs in two copies. A relatively novel approach, here termed MAC-PR (microsatellite allele counting-peak ratios), was used to quantify allelic configuration. Calculation of ratios between the different allele peak areas for each plant thus shows that ratios involving the I-allele peak vary considerably (eg $\mathrm{D}: \mathrm{I}=0.62$ in $R$. dumalis and 0.65 in apomictically derived offspring, but 1.15 in sexually derived offspring), whereas ratios involving the other peaks remain stable (see the Appendix). Consequently, it is suggested that $R$. dumalis has the allelic configuration DIIOP.

In the reciprocal cross ( $R$. rubiginosa $\times R$. dumalis), two offspring groups with four and six plants had been marked down as apomictically- or sexually derived, respectively, according to RAPD marker distribution (Werlemark et al, 1999; Werlemark, 2000). The first group proved to have exactly the same set of microsatellite alleles as the maternal parent. In addition to all of the maternal alleles, the other six offspring also displayed one paternal allele at locus RhEO506. This allele (I) occurred in addition to the two alleles $(D, P)$ which were found in both the parents and the two alleles (J, M) found only in the maternal parent, thus resulting in five alleles (DIJMP). Comparison of peak ratios suggests that the J allele occurs in two copies in $R$. rubiginosa (D:J $=0.63$ ) and in the apomictically derived offspring (D:J $=0.69$ ) but in only one copy in the sexually derived offspring $(\mathrm{D}: \mathrm{J}=1.35)$. Consequently, it is suggested that R. rubiginosa has the allelic configuration DJJMP.
For the $R$. rubiginosa $\times R$. dumalis cross, differences in allele number between apomictically- and sexually derived offspring were noted also for RhD206, RhP507 and RhP519. For locus RhD206, one allele (P) was shared between the parents (Figure 2). In addition, $R$. dumalis had three alleles $(\mathrm{C}, \mathrm{K}, \mathrm{O}), R$. rubiginosa two alleles $(\mathrm{E}, \mathrm{I})$ and their sexually derived offspring four alleles (E, I, O, $\mathrm{P})$. Careful analysis of allelic configuration and peak ratios indicated the existence of two copies of a null allele in $R$. rubiginosa (EIP--), and one copy of this null allele in the sexually derived offspring (EIOP-). Moreover, peak ratio analysis was able to discriminate between apomictically- and sexually derived offspring also in the $R$. dumalis $\times R$. rubiginosa cross, in spite of both groups having the same four alleles $(\mathrm{C}, \mathrm{K}, \mathrm{O}$ and $\mathrm{P})$. The $\mathrm{O}$ allele peak was notably higher in the apomictically derived offspring (CKOOP, O:P =1.92) and in $R$. dumalis itself $(\mathrm{O}: \mathrm{P}=1.62)$ than in the sexually derived offspring $(\mathrm{CKOP}-, \mathrm{O}: \mathrm{P}=0.54)$.

For locus RhP507, one allele (A) was shared between the parents. In addition, $R$. dumalis had two alleles $(G, I)$ as did all of its seedlings. By contrast, sexuallyand apomictically derived seedlings of $R$. rubiginosa differed: the sexually derived seedlings had a paternally derived allele $(\mathrm{G})$, whereas the apomictically derived seedlings were identical to the seed parent. Unfortunately, the $G$ allele peak was very small and the allelic peak ratios therefore quite variable and not as informative as in cases where peaks are more similar in size. 


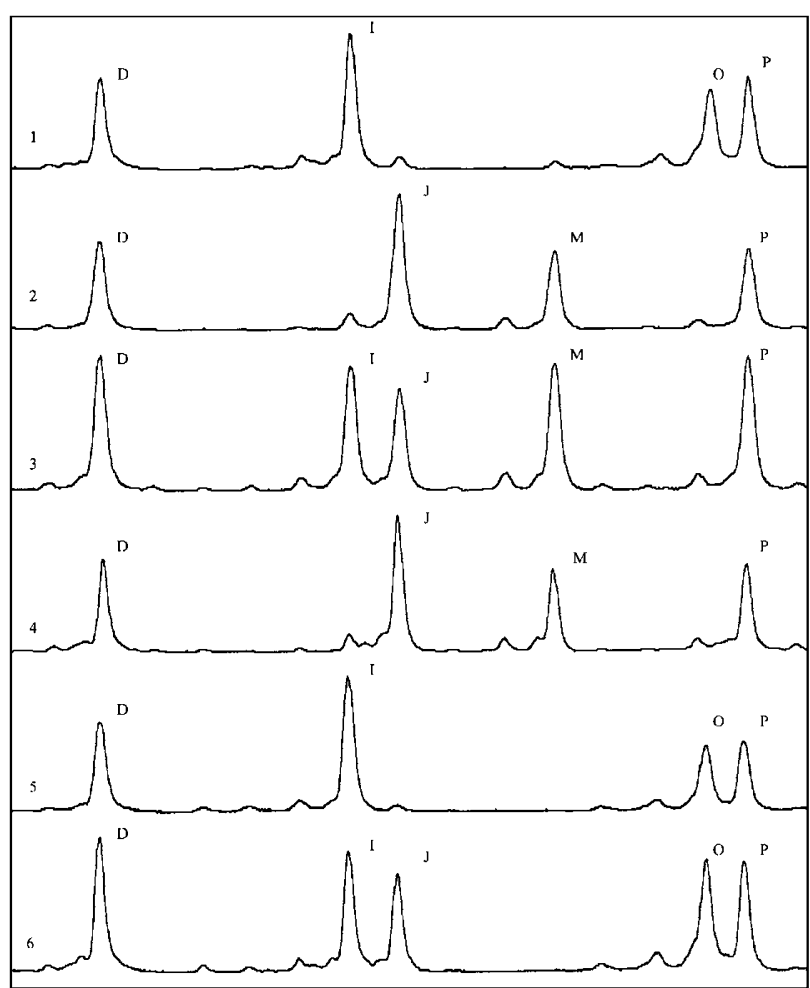

Figure 1 Electrophoretograms of locus RhEO506. Each panel shows the relative fluorescence intensity on the $Y$-axis, with fragments increasing in size from left to right along the $X$-axis. Bold capitals are allelic peaks previously detected in rootstock and hybrid tea varieties. Panels represent the following: 1, $R$. dumalis; 2, $R$. rubiginosa; 3, sexually derived seedling from the cross $R$. rubiginosa (seed parent) $\times R$. dumalis (pollen parent); 4 , apomictically derived seedling from the same cross; 5 , apomictically derived seedling from the cross $R$. dumalis (seed parent) $\times R$. rubiginosa (pollen parent); 6 , sexually derived seedling from the same cross.

Finally, for locus RhP519, the six sexually derived $R$. rubiginosa $\times R$. dumalis plants had a paternally derived allele (C) in addition to the two alleles shared by both parents (F, G). The G:F ratio is higher in R. rubiginosa (0.76) and its apomictically derived offspring (0.69) compared to in the sexually derived offspring (0.47). Tentative allelic configurations would therefore be FFGGG and CFFGG, respectively. Again, peak ratio analysis was able to discriminate between apomicticallyand sexually derived offspring also in the $R$. dumalis $\times$ $R$. rubiginosa cross. Whereas both groups have the same four alleles (C, F, G and J), it is suggested CCFGJ for the first group and CFGGJ for the second.

Looking at the crosses between $R$. dumalis and $R$. rubiginosa, one locus (RhEO506) was able to distinguish apomictically- and sexually derived seedlings in both the crosses. This locus was represented by four alleles in each parent, with two of these alleles being shared. The other three informative loci (RhD206, RhP507 and RhP519) contained four and three alleles with one being shared, three and one alleles with one being shared, and four and two alleles with two being shared. Several other loci in this investigation have similar allelic configurations but could still not discriminate between offspring of a putatively apomictic or sexual origin.

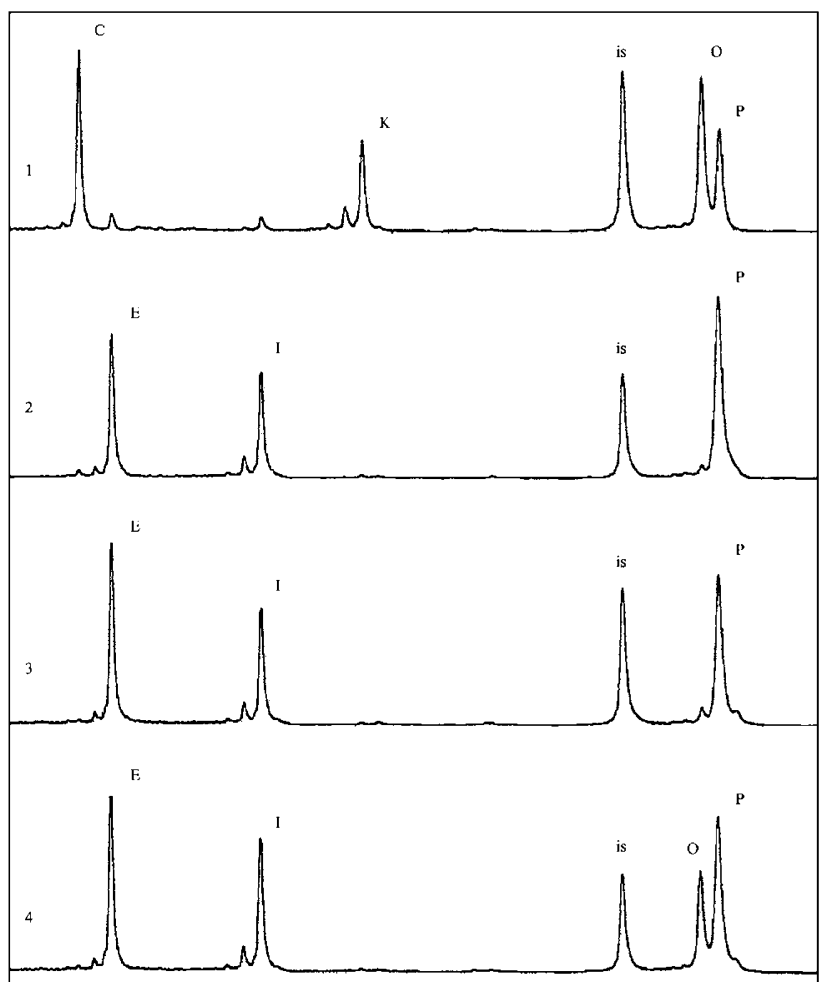

Figure 2 Electrophoretograms of locus RhD206. Each panel shows the relative fluorescence intensity on the $Y$-axis, with fragments increasing in size from left to right along the $X$-axis. Panels represent the following: $1, R$. dumalis; $2, R$. rubiginosa; 3 , apomictically derived seedling from the cross $R$. rubiginosa (seed parent) $\times$ $R$. dumalis (pollen parent); 4, sexually derived seedling from the same cross. Bold capitals are allelic peaks previously detected in rootstock and hybrid tea varieties. is =internal sizer peak. Relationships between E, I and P alleles are rather variable and difficult to interpret, whereas the relationship between $\mathrm{O}$ and $\mathrm{P}$ alleles is quite clear.

In the $R$. sherardii $\times R$. villosa cross, all 10 plants exhibited all of the microsatellite alleles present in the seed parent, $R$. sherardii and none of the two pollenparent-specific alleles. Unfortunately, only six plants were available for analysis in the reciprocal cross, with $R$. villos $a$ as seed parent. Five of these plants showed one pollen-specific allele (B) in the RhM405 locus. The only plant that lacked this allele, had also previously been suggested to have an apomictic origin (Werlemark and Nybom, 2001). R. villosa has only A alleles at this locus. Peak ratio analysis of the other genotypes suggests that $R$. sherardii is $\mathrm{AABBB}$ ( $\mathrm{B}: \mathrm{A}=1.33)$, offspring from $R$. sherardii $\times R$. villosa are $\mathrm{AAABB}(\mathrm{B}: \mathrm{A}=0.64)$, and offspring from $R$. villosa $\times R$. sherardii are $\mathrm{AAAB}(\mathrm{B}: \mathrm{A}=$ $0.36)$.

\section{Discussion}

\section{Marker evaluation}

Comparatively few microsatellite DNA-based investigations have been performed on polyploid species. Moreover, several of the analysed polyploid species are selfing and highly homozygous, and may therefore contain only one allele at each locus (Bryan et al, 1997). In contrast, the large number of bands found in genotypes of outcrossing 
polyploid species often produce smeared patterns that are difficult to interpret (Buteler et al, 1999; Lian et al, 2001). Even unambiguously scored bands are often interpreted as phenotypic banding patterns in polyploids, and no attempts are made to analyse allelic configurations (Provan et al, 1996; Becher et al, 2000; Mengoni et al, 2000). Still, outcrossing polyploid species can be expected to exhibit numerous and different alleles at each individual locus if these can be properly resolved. Amsellem et al (2001) found up to four alleles in the same locus, when analysing tetraploid Rubus alceifolius, and Lian et al (2001) found up to six alleles, when analysing a population of the polyploid Salix reinii, although the ploidy level of the latter species was not determined. Up to six alleles were also found in a set of Rosa genotypes comprising rootstocks, as well as $R$. hybrida varieties (Esselink et al, 2003).

In the present study, individual loci could be unambiguously identified, and almost all of the scored alleles were already known from previous screenings of a large and diverse Rosa collection (Esselink et al, 2003). However, for a more informative interpretation of allelic configurations, the MAC-PR approach, that is, quantitative comparisons of allele peak ratios, proved very useful. Corresponding attempts have been reported in triploid and apomictic Taraxacum genotypes, but it was usually not possible to infer the exact genotype from the relative intensity of bands in those genotypes that showed only two bands (Falque et al, 1998). Carefully optimised experimental conditions are of course a prerequisite for successful quantification of allele copy number. However, the major factor in ensuring success is the possibility to relate the quantification estimates with known (or at least highly likely) allelic configurations in experimentally derived offspring.

\section{Genomic composition}

Analysis of allele peak ratios in the five loci, that were able to distinguish apomictically-and sexually derived seedlings, yielded an unexpected result; all bivalent formation appears to have involved chromosomes with identical microsatellite DNA alleles according to the suggested allelic configurations. These findings are consistent with the fact that it was always one and the same paternal allele that appeared in the sexually derived offspring, in spite of the existence of two or three unique paternal alleles in each of the four loci that were informative in the crosses between $R$. dumalis and $R$. rubiginosa. Extending the allele peak ratio calculations to the remaining loci yielded a consistent pattern (see the Appendix). In each of the four species, bivalents seem to be formed between genomes that must be highly homologous, as they share exactly the same set of microsatellite DNA alleles.

In the three pentaploid species, $R$. dumalis, $R$. sherardii and $R$. rubiginosa, several microsatellite DNA loci were found to contain four simultaneously appearing alleles, but never five. Correspondingly, there were up to three but never four alleles at the loci of tetraploid $R$. villosa. In all likelihood, all three pentaploid species can therefore be regarded as having four different but homeologous genomes, one of which is diploid and three that are haploid. Bivalent formation then takes place primarily between the two members of the diploid genome, whereas the three haploid genomes are transmitted only maternally. Correspondingly, the tetraploid species appears to have one diploid and two haploid genomes. The fact that very few null alleles were detected among the different univalents suggests that these are very similar at the sequence level. Still, structural differences, possibly arising from large rearrangements, might prevent bivalent formation among the univalents. However, it remains remarkable that bivalent forming chromosomes usually share identical microsatellite alleles.

Not only are the bivalent-forming genomes highly similar within a genotype, they also appear to be relatively similar when species are compared. Thus, nine loci appear to form bivalents with chromosomes that have the same alleles when $R$. dumalis and $R$. rubiginosa are compared, whereas different alleles were involved only for four loci. Two of these deviating loci (RhD206 and RhEO506) occur in linkage group 2, one in linkage group 4 (RhP507) and the last (RhP519) has not yet been assigned to a linkage group. Corresponding estimates for the species pair $R$. sherardii and $R$. villosa are 11 loci with identical alleles and one locus (RhM405) with different alleles. Consequently, species-specific alleles appear to be confined mainly to the univalents, which are inherited from the maternal parents only. This explains why so very few pollen-specific alleles are transmitted in interspecific crosses.

Interspecific dog-rose hybrids would, in general, not contain a completely homologous pair of genomes, as the bivalent-forming genomes still differ somewhat between species. This lack of complete homogeneity may be the reason for a lowered meiotic quality and therefore severely lowered pollen quality $(0-10 \%$ in hybrids $v s$ 20-30\% in pure species) (Werlemark, 2000).

Our proposed model for genomic composition is corroborated also by some studies on the nucleolar organisation region in dog-rose chromosomes. Each of the five genomes in $R$. canina appears to have a single ribosomal DNA locus, based on consistently finding five loci in FISH investigations (Lim et al, unpublished data). Two of these loci differ cytologically by being either very small or very large. Bivalent formation always takes place among two of the remaining three loci, which cannot be differentiated cytologically. Sequencing parts of this region (rDNA ITS1) has yielded four different sequences within a single $5 \times$ genotype of $R$. canina, two different sequences within a single $4 \times$ genotype of R. gallica (Sect. Gallicanae) and three different sequences within a single $6 \times$ genotype of $R$. jundzilli (thought to be a hybrid between $R$. gallica and one of the species in Sect. Caninae) (Wisseman, 1999). One of the $R$. canina sequences (Type A) occurred also in R. jundzilli and in $R$. gallica. Another sequence (Type C), shared only between $R$. canina and $R$. jundzilli, appears to have a higher ratio in $R$. canina than the other three DNA clones isolated from this genotype. Consequently, the Type $C$ sequence may occur in a diploid genome, whereas the other three sequences occur in one haploid genome each.

Hurst (1927) suggested that $5 \times$ species each have three haploid genomes and one diploid. According to his model, different genomes are diploid in different species. Moreover, the diploid genome in one species should have haploid counterparts in other species. Reciprocal interspecific crosses should therefore yield identical 
results. This is, however, clearly not the case when morphological traits or DNA markers are evaluated (Werlemark et al, 1999; Werlemark, 2000; Werlemark and Nybom, 2001). Gustafsson and Håkansson (1942) instead suggested that dog-roses are autotriploid. This means that, in addition to two different, haploid genomes, each species should also have one triploid genome. A good explanation for the lack of trivalents has, however, never been presented.

Lim et al (unpublished data) investigated a dog-rose plant derived from a reduced $4 \times$ egg cell of $R$. canina that had been pollinated with irradiated and presumably mostly sterile pollen. This plant had a very aberrant meiosis with no, or very few, bivalents. Obviously, the genome normally transmitted from the pollen parent is necessary for proper bivalent formation. By contrast, Rosa genomes from other sections (Synstylae and Cassiorhodon $=$ Rosa) are capable of high rates of bivalent formation in diploid intersectional hybrids, and similarly high rates of multivalent formation in tetraploid hybrids (Ma et al, 2000). A specific mechanism must be responsible for the strictly determined bivalent formation in dog-roses. Fagerlind (1944) proposed some kind of genetic control, Blackhurst (1948) suggested that chromosome pairing is regulated by a series of alleles, and Roberts (1975) described a model with different genes responsible for the pollen mother cell (PMC) and embryo mother cell (EMC). A genetically determined bivalent-promoting mechanism has been suggested in other species, for example, Dahlia (Gatt et al, 1999).

\section{Marker inheritance}

The configuration with one diploid genome and two or three haploid genomes, and with bivalent formation mainly involving the diploid and highly homozygous genome, creates a situation very similar to apomixis. Most loci show no recombination in the interspecific hybrids, since the same pair of identical alleles are found in both species and take part in bivalent formation. Instead, the majority of the species-specific alleles are inherited as univalents and passed on only through the maternal parent.

Previously obtained results using the RAPD method in dog-roses show that pollen parent-specific markers are usually inherited by all or nearly all offspring, or, alternatively, by none, or almost none, of the offspring (Werlemark et al, 1999; Werlemark and Nybom, 2001). In five interspecific dog-rose crosses involving the same set of species as the present study, a total of 43 pollen parentspecific markers were scored in the sexually derived seedlings. Of these markers, 11 occurred in all of the offspring, and another four occurred in 86-94\% of the offspring. Conversely, 16 of the markers were not found in any of offspring, three in 1-10\% and seven in 11-20\%. Only two out of all these markers showed more intermediate distributions, as they were encountered in 70 and in 40\%, respectively. Allowing for occasional mispairings and/or minor structural differences between the chromosomes in the diploid genome, these results suggest that 15 or 16 of these RAPD markers occur on both of the bivalent-forming chromosomes in the pollen meiosis, and thus are transmitted to almost all of the offspring. The remaining 26 or 27 markers instead appear to occur on the univalent-forming chromosomes and thus are seldom transmitted.

According to the microsatellite DNA data, the bivalent-forming genomes are very similar within species. Most of the offspring should therefore be very homogeneous, regardless of whether derived from apomixis, selfing or from intraspecific cross-pollination. Previous RAPD investigations of seedling families obtained after open pollination in natural populations have indeed shown extremely high levels of homogeneity in the investigated species, $R$. dumalis and $R$. rubiginosa (Olsson, 1999).

\section{Species differentiation and evolution}

Morphological trait analysis (manually scored reproductive characters and image analysis of leaf shape), as well as RAPDs, has demonstrated that intraspecific variation is sparse in the section Caninae (Nybom et al, 1996, 1997; Olsson et al, 2000). This suggests that the presently analysed four parental plants can be regarded as quite representative of their respective species, and may even be used to predict levels of intraspecific variability. Although overall low, the amount of intraspecific variation appears to vary somewhat between species. In morphologically- and RAPD-based studies, $R$. dumalis (both subsp. coriifolia and subsp. dumalis) usually stands out as being the most variable species and $R$. rubiginosa the least. Like $R$. dumalis, $R$. villosa subsp. mollis shows significant between-population variability, whereas it is more similar to $R$. rubiginosa in showing very little within-population variability (Nybom et al, 1997). In the present study, the number of microsatellite alleles per locus was rather similar, suggesting that levels of heterozygosity do not differ much between the four plants. Yet a small decrease in relative number of alleles was noted from $R$. dumalis through $R$. sherardii and $R$. villosa, to $R$. rubiginosa.

Since it is highly unlikely that the peculiar canina meiosis has evolved more than once, the present-day existence of approx. 20-30 dog-rose species must stem from a common ancestor. Possibly there was originally a sterile triploid interspecific hybrid that underwent duplication of one genome and thus achieved restoration of fertility. The canina meiosis then evolved to ensure reproductive success in the new taxon. Interspecific hybridization at the polyploid level appears to be the most plausible mode for the following speciation events. Dog-roses are generally thought to be alloploids (Blackhurst, 1948) or autoalloploids (Grant, 1971) depending on how much the structural differences between the genomes are emphasised.

In fully sexual, mainly outcrossing species, natural selection would have rapidly differentiated the hybrids morphologically in order to adapt them to different environments. Moreover, the parental genes in any hybrid could have undergone diversification or even become silenced through mutational or epigenetical means, as well as have started to interact with each other through recombination (Wendel, 2000). However, because of the reduced levels of recombination in dogroses due to hemisexuality and apomixis, the original genomes may instead have been retained to a considerable extent.

The relatively high levels of microsatellite DNA polymorphism reported here, as compared to the 
restricted variation observed in RAPD analysis (Werlemark and Nybom, 2001), suggests that microsatellites may become a very useful tool for studying interspecific relationships and speciation in dog-roses.

\section{Acknowledgements}

Valuable comments on the manuscript were given by Dr S Rajapakse. Financial support was received from the Erik Philip-Sörensen foundation and from the Swedish Research Council for Forestry and Agriculture.

\section{References}

Amsellem L, Dutech C, Billotte N (2001). Isolation and characterization of polymorphic microsatellite loci in Rubus alceifolius Poir. (Rosaceae), an invasive weed in La Réunion island. Mol Ecol Notes 1: 33-35.

Becher SA, Steinmetz K, Weising K, Boury S, Peltier D, Renou $\mathrm{J}-\mathrm{P}$, et al (2000). Microsatellites for cultivar identification in Pelargonium. Theor Appl Genet 101: 643-651.

Blackburn K, Heslop-Harrison JW (1921). The status of the British rose forms as determined by their cytological behaviour. Ann Bot 35: 159-188.

Blackhurst HT (1948). Cytogenetic studies on Rosa rubiginosa and its hybrids. Proc Am Soc Hort Sci 52: 510-516.

Bryan GJ, Collins AJ, Stephenson P, Orry A, Smith JB, Gale MD (1997). Isolation and characterisation of microsatellites from hexaploid bread wheat. Theor Appl Genet 94: 557-563.

Buteler MI, Jarret RL, LaBonte DR (1999). Sequence characterization of microsatellites in diploid and polyploid Ipomoea. Theor Appl Genet 99: 123-132.

Debener T, Mattiesch L, Vosman B (2001). A molecular marker map for roses. Acta Hort 547: 283-287.

Esselink GD, Smulders MJM, Vosman B (2003). Identification of cut rose (Rosa hybrida) and rootstock varieties using robust sequence tagged microsatellite site markers. Theor Appl Genet 106: 277-286.

Fagerlind F (1944). Kompatibilität und inkompatibilität in der Gattung Rosa. Acta Horti Bergiani 13: 274-302.

Falque M, Keurentjes J, Bakx-Schotman JMT, van Dijk PJ (1998). Development and characterization of microsatellite markers in the sexual-apomictic complex Taraxacum officinale (dandelion). Theor Appl Genet 97: 283-292.

Gatt M, Hammett K, Murray B (1999). Confirmation of ancient polyploidy in Dahlia (Asteraceae) species using genomic in situ hybridization. Ann Bot 84: 39-48.

Grant V (1971). Plant Speciation. Columbia Press: New York.

Guilford P, Prakash S, Zhu JM, Rikkerink E, Gardiner S, Bassett $\mathrm{H}$ et al (1997). Microsatellites in Malus $\times$ domestica (apple): abundance, polymorphism and cultivar identification. Theor Appl Genet 94: 249-254.

Gustafsson $\AA$ (1944). The constitution of the Rosa canina complex. Hereditas 30: 405-428.

Gustafsson A, Håkansson A (1942). Meiosis in some Rosahybrids. Bot Notiser 95: 331-343.

Hokanson SC, Szewc-McFadden AK, Lamboy WF, McFerson JR (1998). Microsatellite (SSR) markers reveal genetic identities, genetic diversity and relationships in a Malus $\times$ domestica Borkh. core subset collection. Theor Appl Genet 97: 671-683.

Holm S (1995). Unexpected high levels of genetic variation in Potentilla argentea L. (s.l.) in southern Sweden. Hereditas 123: 127-139.

Hurst CC (1927). Differential polyploidy in the genus Rosa L. Z Induk Abstamm-Ver Suppl, 2: 866-906.

Jones CJ, Edwards KJ, Castiglione S, Winfield MO, Sala F, Van de Wiel C et al (1997). Reproducibility testing of RAPD, AFLP and SSR markers in plants by a network of European laboratories. Mol Breeding 3: 381-390.
Klasterska I, Klastersky I (1974). Cytology and some chromosome numbers of Czechoslovak roses II. Bot Notiser 127: 328-337.

Kroon GH, Zeilinga AE (1974). Apomixis and heterogamy in rose rootstocks (Rosa canina L.). Euphytica 23: 345-352.

Lian C, Nara K, Nakaya H, Zhou Z, Wu B, Miyashita N et al (2001). Development of microsatellite markers in polyploid Salix reinii. Mol Ecol Notes 1: 160-161.

Ma Y, Crane CF, Byrne DH (2000). Meiotic behavior in a tetraploid rose and its hybrid progeny. HortScience 35: 11271131.

Mengoni A, Gori A, Bazzicalupo M (2000). Use of RAPD and microsatellite (SSR) variation to assess genetic relationships among populations of tetraploid alfalfa, Medicago sativa. Plant Breeding 119: 311-317.

Nilsson OO (1967). Drawings of Scandinavian plants 1-8, Rosa L. Bot Notiser 120: 1-8, 137-143, 249-254, 393-408.

Nybom H, Carlson-Nilsson U, Werlemark G, Uggla M (1997). Different levels of morphometric variation in three heterogamous dogrose species (Rosa Sect. Caninae). Pl Syst Evol 204: 207-224.

Nybom H, Olsson Å, Werlemark G (1996). Morphometric variation in Nordic dogroses (Rosa sect. Caninae, Rosaceae). Symb Bot Ups 31: 59-68.

Olsson ÅME (1999). Morphometric and molecular variation in the Nordic dogroses (Rosa sect. Caninae, Rosaceae). PhD Thesis, Lund University, Sweden.

Olsson A, Nybom H, Prentice HC (2000). Relationships between Nordic dogroses (Rosa L. sect. Caninae, Rosaceae) assessed by RAPDs and elliptic Fourier analysis of leaflet shape. Syst Bot 25: 511-521

Provan J, Powell W, Waugh R (1996). Microsatellite analysis of relationships within cultivated potato (Solanum tuberosum). Theor Appl Genet 92: 1078-1084.

Roberts AV (1975). The nature and taxonomic significance of the system of inheritance in Rosa nanothamnus (Rosaceae). Bot J Linn Soc 71: 59-66.

Sosinski B, Gannavarapu M, Hager LD, Beck LE, King GJ, Ryder CD et al (2000). Characterization of microsatellite markers in peach [Prunus persica (L.) Batsch]. Theor Appl Genet 101: 421-428

Täckholm G (1920). On the cytology of the genus Rosa. Svensk Bot Tidskrift 14: 300-311.

Täckholm G (1922). Zytologische Studien über die Gattung Rosa. Acta Horti Bergiani 7: 97-381.

Wendel JF (2000). Genome evolution in polyploids. Plant Mol Biol 42: 225-249.

Werlemark G (2000). Evidence of apomixis in hemisexual dogrose species. Rosa sect. Caninae. Sexual Plant Reprod 12: 353-359.

Werlemark G, Nybom H (2001). Skewed distribution of morphological character scores and molecular markers in three interspecific crosses in Rosa section Caninae. Hereditas 134: 1-13.

Werlemark G, Uggla M, Nybom H (1999). Highly skewed distribution of morphological and RAPD markers in a pair of reciprocal crosses between hemisexual dogrose species, Rosa sect. Caninae. Theor Appl Genet 98: 557-563.

Wisseman V (1999). Genetic constitution of Rosa Sect. Caninae (R. canina, R. jundzillii) and Sect. Gallicanae (R. gallica). J Appl Bot 73: 191-196.

Wisseman V, Hellwig FH (1997). Reproduction and hybridisation in the genus Rosa, Section Caninae (Ser.) Rehd. Bot Acta 110: 251-256.

Zielinski J (1985). Studia nad radzajem Rosa L. - Systematika sekcji Caninae DC. em. Christ. Arboretum Körnickie Rocznik 30: 3-109.

\section{Appendix}

Tentative allelic configuration in 15 microsatellite DNA loci. Alleles that are unique for one of the parents in each 
cross combination ( $R$. dumalis $\times R$. rubiginosa and its reciprocal, and $R$. sherardii $\times R$. villosa and its reciprocal) are given in bold. Alleles in the offspring that appear to have been inherited from the pollen parent are given in italics. The apparently bivalent-forming alleles are underlined. - denotes putative null alleles. Average peak ratios (and range within parantheses) are calculated for pairwise peak comparisons for $R$. dumalis, for five of its apomictically derived seedling (denoted A), for five of its sexually derived seedling (denoted $S$ ), for $R$. rubiginosa, for four of its apomictically derived seedlings, for six of its sexually derived seedlings, for $R$. sherardii, for 10 of its sexually derived seedlings, for $R$. villosa, for a single apomictically derived seedling and for five of its sexually derived seedlings. * One missing value. Seedling no. 158 showed a deviating profile for locus RhP519 and is shown separately from its siblings.

\begin{tabular}{|c|c|c|c|c|}
\hline & & & eak ratios & \\
\hline Locus RhAB13 & & B:E & C:E & $\mathrm{I}: \mathrm{E}$ \\
\hline R. dumalis & BCEEI & 0.67 & 0.61 & 0.30 \\
\hline R. $d \times r_{.}, \mathrm{A}$ & BCEEI & $0.68(0.64-0.75)$ & $0.58(0.52-0.61)$ & $0.31(0.31-0.32)$ \\
\hline R. $d \times r_{.}, \mathrm{S}$ & BCEEI & $0.89(0.83-1.09)$ & $0.75(0.70-0.83)$ & $0.36(0.23-0.46)$ \\
\hline & & B:E & $\mathrm{C}: \mathrm{E}$ & $\mathrm{G}: \mathrm{E}$ \\
\hline R. rubiginosa & BCEEG & 0.63 & 0.54 & 0.33 \\
\hline R. $r . \times \stackrel{d}{d}, \mathrm{~A}$ & $\mathrm{BCEEG}$ & $0.63(0.57-0.68)$ & $0.55(0.42-0.70)$ & $0.29(0.27-0.32)$ \\
\hline R. $r . \times d ., \mathrm{S}$ & BCEEG & $0.74(0.62-0.94)$ & $0.67(0.57-0.94)$ & $0.31(0.25-0.34)$ \\
\hline & & $\mathrm{B}: \mathrm{E}$ & $\mathrm{C}: \mathrm{E}$ & $\mathrm{I}: \mathrm{E}$ \\
\hline R. sherardii & BCEEI & 0.56 & 0.43 & 0.35 \\
\hline R. s. $\times v ., \mathrm{S}$ & $\mathrm{BCEE}$ & $0.56(0.51-0.72)$ & $0.44(0.40-0.49)$ & $0.33(0.28-0.44)$ \\
\hline & & $B: E$ & & $\mathrm{I}: \mathrm{E}$ \\
\hline R. villosa & BEEI & 0.58 & & 0.37 \\
\hline R. $v . \times$ s., A & BEEI & 0.61 & & 0.39 \\
\hline R. $v . \times s ., \mathrm{S}$ & BEEI & $0.49(0.45-0.52)$ & & $0.35(0.32-0.42)$ \\
\hline
\end{tabular}

Bivalent formation is suggested to involve two copies of the E-allele in all four species, but the B-allele cannot be ruled out since there is a stable relationship between B and E. However, the former has a considerably smaller peak and is therefore less likely to occur in two copies.

$\begin{array}{llll}\text { Locus RhAB15 } & & \text { M:E } & \text { M:L } \\ R . d u m a l i s & \text { EELLM } & 0.24 & 0.62 \\ R . d . \times r ., \mathrm{A} & \text { EELLM } & 0.34(0.17-0.44) & 0.53(0.33-0.62) \\ R . d . \times r ., \mathrm{S} & \text { EELLM } & 0.28(0.09-0.77) & 0.44(0.18-0.61) \\ & & \mathrm{N}: \mathrm{D} & \mathrm{N}: \mathrm{E} \\ R . \text { rubignosa } & \text { DDEEN } & 0.24 & 0.34 \\ R . r \times d ., \mathrm{A} & \text { DDEEN } & 0.19(0.17-0.23) & 0.28(0.27-0.32) \\ R . r \times d ., \mathrm{S} & \text { DDEEN } & 0.20(0.13-0.26) & 0.34(0.25-0.42) \\ & & \mathrm{F}: \mathrm{D} & \mathrm{M}: \mathrm{D} \\ R . \text { sherardii } & \text { DDFFM } & 0.92 & 0.33 \\ R . s . \times v ., \mathrm{S} & \text { DDFFM } & 0.68(0.49-0.99) & 0.26(0.23-0.27) \\ & & \text { F:D } & \\ R . v i l l o s a & \text { DDFF } & 0.93 & \\ R . v . \times s ., \mathrm{A} & \text { DDFF } & 0.85 & \\ R . v . \times s ., \mathrm{S} & \text { DDFF } & 0.83(0.76-0.89) & \end{array}$

Bivalent formation in $R$. sherardii and $R$. villosa may involve either the $\mathrm{F}$ or $\mathrm{D}$ alleles.

\section{Locus RhAB22}

R. dumalis

R. $d . \times r, \mathrm{~A}$

R. $d . \times r ., \mathrm{S}$

R. rubiginosa

R. $r . \times d$., A

R. $r . \times d ., \mathrm{S}$

R. sherardii

R. s. $\times$ v., $\mathrm{S}$

R. villosa

R. $v . \times s ., \mathrm{A}$

R. v. $\times$ s., $\mathrm{S}$
GGGGG

GGGGG

GGGGG

$\begin{array}{ll} & \text { I:G } \\ \text { GGIII } & 1.05 \\ \text { GGIII } & 1.25(1.20-1.28) \\ \text { GGIII } & 1.24(1.18-1.29) \\ & \text { H:G } \\ \text { GGGHH } & 0.89 \\ \text { GGGHH } & 0.94(0.90-0.98)\end{array}$

HHHH

$\mathrm{HHHH}$

$\mathrm{HHHH}$ 
148

\begin{tabular}{|c|c|c|c|c|}
\hline Locus RhAB26 & & $\mathrm{L}: \mathrm{G}$ & $\mathrm{G}_{1}: \mathrm{G}$ & \\
\hline R. dumalis & $\mathrm{GGG}_{1} \mathrm{G}_{1} \mathrm{~L}$ & 0.30 & 0.91 & \\
\hline R. $d . \times r_{.}, \mathrm{A}^{* 1}$ & $\mathrm{GGG}_{1} \mathrm{G}_{1} \mathrm{~L}$ & $0.28(0.22-0.35)$ & $0.80(0.56-1.03)$ & \\
\hline R. $d . \times r ., \mathrm{S}$ & $\mathrm{GGG}_{\mathbf{1}} \mathrm{G}_{\mathbf{1}} \mathrm{L}$ & $0.25(0.03-0.37)$ & $0.89(0.60-1.03)$ & \\
\hline $\begin{array}{l}\text { R. rubiginosa } \\
\text { R. } r . \times d ., \mathrm{A} \\
R . r . \times d ., \mathrm{S}\end{array}$ & $\begin{array}{l}\text { AEGGL } \\
\text { AEGGL } \\
\text { AEGGL }\end{array}$ & $\begin{array}{l}\text { L:G } \\
0.55 \\
0.20(0.07-0.34) \\
0.45(0.13-0.84)\end{array}$ & $\begin{array}{l}\text { A:G } \\
0.26 \\
0.21(0.18-0.23) \\
0.21(0.07-0.46)\end{array}$ & $\begin{array}{l}\text { E:G } \\
0.52 \\
0.34(0.24-0.42) \\
0.34(0.22-0.56)\end{array}$ \\
\hline $\begin{array}{l}\text { R. sherardii } \\
\text { R. s. } \times \text { v., } \mathrm{S}\end{array}$ & $\begin{array}{l}\text { CCGGL } \\
\text { CCGGL }\end{array}$ & $\begin{array}{l}\mathrm{L}: \mathrm{G} \\
0.25 \\
0.23(016-0.39)\end{array}$ & $\begin{array}{l}\text { C:G } \\
0.62 \\
0.73(0.56-0.88)\end{array}$ & \\
\hline $\begin{array}{l}\text { R. villosa } \\
\text { R. v. } \times \text { s., } \mathrm{A} \\
R . v . \times s ., \mathrm{S}\end{array}$ & $\begin{array}{l}\text { CCGG } \\
\text { CCGG } \\
\text { CCGG }\end{array}$ & & $\begin{array}{l}C: G \\
0.69 \\
0.62 \\
0.63(0.59-0.70)\end{array}$ & \\
\hline
\end{tabular}

Bivalent formation in $R$. dumalis and R. rubiginosa is suggested to involve two copies of the G allele but the $\mathrm{L}$ allele cannot be ruled out, although it has a much smaller peak. Bivalent formation in $R$. sherardii and $R$. villosa may involve either the $C$ or $G$ alleles.

\begin{tabular}{|c|c|c|c|c|}
\hline Locus RhB303 & & $\mathrm{B}: \mathrm{D}$ & A:D & $F: D$ \\
\hline R. dumalis & ABDDF & 0.65 & 0.57 & 0.41 \\
\hline R. $d . \times r_{.}, \mathrm{A}$ & $\mathrm{ABDD} \mathbf{F}$ & $0.56(0.52-0.62)$ & $0.56(0.52-0.61)$ & $0.36(0.34-0.37)$ \\
\hline R. $d . \times r ., \mathrm{S}$ & $\mathbf{A B D D F}$ & $0.54(.51-0.58)$ & $0.55(0.52-0.60)$ & $0.33(0.31-0.37)$ \\
\hline $\begin{array}{l}\text { R. rubiginosa } \\
\text { R. r. } \times d ., \mathrm{A} \\
\text { R. } r . \times d ., \mathrm{S}\end{array}$ & $\begin{array}{l}\text { BBBDD } \\
\text { BBBDD } \\
\text { BBBDD }\end{array}$ & $\begin{array}{l}\text { B:D } \\
1.61 \\
1.58(1.33-1.79) \\
1.70(1.53-1.84)\end{array}$ & & \\
\hline $\begin{array}{l}\text { R. sherardii } \\
\text { R. s. } \times \text { v., } \mathrm{S}\end{array}$ & $\begin{array}{l}\text { ABDDE } \\
\text { ABDDE }\end{array}$ & $\begin{array}{l}\text { B:D } \\
0.52 \\
0.53(0.46-0.61)\end{array}$ & $\begin{array}{l}\text { A:D } \\
0.55 \\
0.53(0.49-0.56)\end{array}$ & $\begin{array}{l}\text { E:D } \\
0.40 \\
0.36(0.33-0.39)\end{array}$ \\
\hline $\begin{array}{l}\text { R. villosa } \\
\text { R. v. } \times \text { s., } \mathrm{A} \\
\text { R. v. } \times \text { s., } \mathrm{S}\end{array}$ & $\begin{array}{l}\text { BDDE } \\
\text { BDDE } \\
\text { BDDE }\end{array}$ & $\begin{array}{l}\text { B:D } \\
0.54 \\
0.58 \\
0.58(0.53-0.64)\end{array}$ & & $\begin{array}{l}\text { E:D } \\
0.37 \\
0.38 \\
0.37(0.34-0.41)\end{array}$ \\
\hline $\begin{array}{l}\text { Locus RhD201 } \\
\text { R. dumalis } \\
\text { R. d. } \times r ., \mathrm{A}^{* 1} \\
R . d . \times r ., \mathrm{S}^{* 1}\end{array}$ & $\begin{array}{l}\text { EEFHJ } \\
\text { EEFHJ } \\
\text { EEFHJ }\end{array}$ & $\begin{array}{l}\mathrm{H}: \mathrm{E} \\
0.24 \\
0.16(0.07-0.21) \\
0.14(0.03-0.19)\end{array}$ & $\begin{array}{l}\text { F:E } \\
0.36 \\
0.32(0.28-0.35) \\
0.34(0.31-0.35)\end{array}$ & $\begin{array}{l}\text { J:E } \\
0.41 \\
0.25(0.17-0.29) \\
0.26(0.12-0.34)\end{array}$ \\
\hline $\begin{array}{l}\text { R. rubiginosa } \\
\text { R. } r . \times d ., \mathrm{A} \\
R . r . \times d ., \mathrm{S}\end{array}$ & $\begin{array}{l}\text { AEEHM } \\
\text { AEEHM } \\
\text { AEEHM }\end{array}$ & $\begin{array}{l}\text { H:E } \\
0.25 \\
0.20(0.19-0.22) \\
0.20(0.17-0.21)\end{array}$ & $\begin{array}{l}\text { A:E } \\
0.54 \\
0.53(0.51-0.59) \\
0.52(0.48-0.58)\end{array}$ & $\begin{array}{l}\text { M:E } \\
0.28 \\
0.28(0.25-0.30) \\
0.27(0.23-0.31)\end{array}$ \\
\hline $\begin{array}{l}\text { R. sherardii } \\
\text { R. s. } \times v ., \mathrm{S}\end{array}$ & $\begin{array}{l}\text { EEHHK } \\
\text { EEHHK }\end{array}$ & $\begin{array}{l}\text { H:E } \\
0.32 \\
0.23(0.15-0.28)\end{array}$ & $\begin{array}{l}\mathrm{K}: \mathrm{E} \\
0.39 \\
0.31(0.25-0.36)\end{array}$ & \\
\hline $\begin{array}{l}\text { R. villosa } \\
\text { R. v. } \times \text { s., } \mathrm{A} \\
\text { R. v. } \times \text { s., } \mathrm{S}\end{array}$ & $\begin{array}{l}\text { EEHH } \\
\text { EEHH } \\
\text { EEHH }\end{array}$ & $\begin{array}{l}\mathrm{H}: \mathrm{E} \\
0.30 \\
0.20 \\
0.21(0.15-0.27)\end{array}$ & & \\
\hline
\end{tabular}

The proportions between the $\mathrm{E}$ and $\mathrm{H}$ alleles overlap when all species and offspring families are compared, but it is difficult to envision a model with the same proportions between these alleles in the whole material.

Locus RhD206

R. dumalis

R. d. $\times$ r., A

R. $d . \times r ., \mathrm{S}$

R. rubiginosa

R. $r . \times d ., \mathrm{A}$

R. $r . \times d ., \mathrm{S}$

R. sherardii

R. s. $\times$ v., S

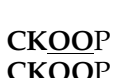

CKOOP

CKOP-

$\mathrm{EIP}_{=-}$

EIP - -

EIOP-

CKOQQ

CKOQQQ
$\mathrm{O}: \mathrm{C}$

1.25

$0.83(0.43-1.31)$

$0.31(0.08-0.60)$

E:P

0.39

$0.75(0.59-0.85)$

$0.91(0.72-1.08)$

$\mathrm{O}: \mathrm{C}$

0.40

$0.38(0.17-0.65)$
$\mathrm{K}: \mathrm{C}$

0.55

$0.45(0.35-0.78)$

$0.35(0.21-0.59)$

I:P

0.29

$0.55(0.54-0.57)$

$0.69(0.50-0.86)$

$\mathrm{K}: \mathrm{C}$

0.49

$0.42(0.28-0.53)$
O:P

1.62

$1.92(1.80-2.17)$

$0.54(0.49-0.58)$

0.45

$0.63(0.45-0.69)$

$1.61(0.99-2.50)$

$\mathrm{O}: \mathrm{P}$

-

$0.61(0.56-0.70)$

Q:C

0.60

$0.58(0.25-1.06)$
$\mathrm{K}: \mathrm{O}$

1.25

$1.21(0.82-1.66)$ 


$\begin{array}{llll} & & \mathrm{O}: \mathrm{C} & \\ R . v i l l o s a & \text { COQQ } & 0.34 & \\ \text { R. } v . \times \text { s., A } & \text { COQQ } & 0.39 & \\ \text { R. } v . \times \text { s., } \mathrm{S}^{* 1} & \text { COQQ } & 0.36(0.20-0.52) & \\ & & \mathrm{C}: \mathrm{B} & \mathrm{G}: \mathrm{B} \\ \text { Locus RhD221 } & & 0.55 & 0.44 \\ \text { R. sherardii } & \text { BBCCG } & 0.58(0.46-0.64) & 0.52(0.45-0.63) \\ \text { R. s. } \times \text { v., S } & \text { BBCCG } & & \\ & & \mathrm{C}: \mathrm{B} & \\ \text { R. villosa } & & 0.75 & \\ \text { R. } v . \times \text { s., A } & \text { BBCC } & 0.77 & \\ \text { R. } v . \times \text { s., S } & \text { BBCC } & 0.66(0.60-0.77) & \end{array}$

\section{Q:C}

0.52

0.66

$0.65(0.34-0.96)$

Both R. dumalis and R. rubiginosa have the B, C and $\mathrm{G}$ alleles at this locus, and their progeny was therefore not investigated. Bivalent formation in $R$ sherardii and $R$. villosa may involve either the B or $C$ alleles.

\begin{tabular}{|c|c|c|c|c|c|}
\hline Locus RhE2b & & $\mathrm{B}: \mathrm{C}$ & $\mathrm{E}: \mathrm{C}$ & $\mathrm{I}: \mathrm{C}$ & \\
\hline R. dumalis & BCCEI & 0.62 & 0.37 & 0.24 & \\
\hline R. $d . \times r_{.}, \mathrm{A}$ & BCCEI & $0.63(0.62-0.67)$ & $0.39(0.34-0.46)$ & $0.16(0.12-0.21)$ & \\
\hline$R . d . \times r ., \mathrm{S}$ & BCCEI & $0.64(0.62-0.69)$ & $0.40(0.38-0.42)$ & $0.19(0.15-0.22)$ & \\
\hline $\begin{array}{l}\text { R. rubiginosa } \\
\text { R. r. } \times d ., \mathrm{A} \\
\text { R. r. } \times d ., \mathrm{S}\end{array}$ & $\begin{array}{l}\text { BCCFI } \\
\text { BCCFI } \\
\text { BCCFI }\end{array}$ & $\begin{array}{l}\text { B:C } \\
0.62 \\
0.54(0.39-0.65) \\
0.65(0.61-0.70)\end{array}$ & & $\begin{array}{l}\text { I:C } \\
0.14 \\
0.26(0.19-0.34) \\
0.19(0.14-0.22)\end{array}$ & $\begin{array}{l}\text { F:C } \\
0.38 \\
0.42(0.41-0.43) \\
0.40(0.37-0.41)\end{array}$ \\
\hline $\begin{array}{l}\text { R. sherardii } \\
\text { R. s. } \times \text { v., } \mathrm{S}\end{array}$ & $\begin{array}{l}\text { BCCEI } \\
\text { BCCEI }\end{array}$ & $\begin{array}{l}\text { B:C } \\
0.60 \\
0.66(0.62-0.78)\end{array}$ & $\begin{array}{l}\text { E:C } \\
0.42 \\
0.39(0.35-0.46)\end{array}$ & $\begin{array}{l}\text { I:C } \\
0.21 \\
0.19(0.16-0.22)\end{array}$ & \\
\hline $\begin{array}{l}\text { R. villosa } \\
\text { R. v. } \times \text { s., } \mathrm{A} \\
\text { R. v. } \times \text { s., } \mathrm{S}^{* 1}\end{array}$ & $\begin{array}{l}\text { BCCE } \\
\text { BCCE } \\
\text { BCCE }\end{array}$ & $\begin{array}{l}\text { B:C } \\
0.60 \\
0.66 \\
0.67(0.65-0.71)\end{array}$ & $\begin{array}{l}\text { E:C } \\
0.45 \\
0.32 \\
0.36(0.33-0.38)\end{array}$ & & \\
\hline
\end{tabular}

Bivalent formation is suggested to involve two copies of the $\mathrm{C}$ allele in all four species but the $\mathrm{B}$ allele cannot be ruled out, although it has a smaller peak.

\section{Locus RhEO506}

$R$. dumalis

R. $d . \times r ., \mathrm{A}$

R.d. $\times r ., \mathrm{S}$

R. rubiginosa

R. $r . \times$ d., A

R. $r . \times d ., \mathrm{S}$

R. sherardii

R. $s . \times v ., \mathrm{S}$

R. villosa

R. v. $\times$ s., $\mathrm{A}$

R. v. $\times$ s., $\mathrm{S}$

Locus RhJ404

$R$. dumalis

R. $d . \times r ., \mathrm{A}$

R. d. $\times r ., \mathrm{S}$

R. rubiginosa

R. $r . \times d ., \mathrm{A}$

R. $r . \times d ., \mathrm{S}$

$\begin{array}{ll} & \text { D:I } \\ \text { DIIOP } & 0.62 \\ \text { DIIOP } & 0.65(0.62-0.67) \\ \text { DIJOP } & 1.15(1.12-1.21) \\ & \\ & \text { D:I } \\ \text { DJJMP } & - \\ \text { DJJMP } & - \\ \text { DIJMP } & 1.14(0.93-1.41) \\ & \text { D:I } \\ \text { DIINP } & 0.63 \\ \text { DIINP } & 0.64(0.58-0.69) \\ & \text { D:I } \\ \text { DIIO } & 0.67 \\ \text { DIIO } & 0.67 \\ \text { DIIO } & 0.68(0.61-0.71) \\ & \\ \text { BBBBB } & \\ \text { BBBBB } & \\ \text { BBBBB } & \\ & \\ \text { BBBGG } & \text { G:B } \\ \text { BBBGG } & 0.66 \\ \text { BBBGG } & 0.42(0.23-0.61) \\ & 0.42(0.24-0.68)\end{array}$

\section{D:}

$-$

$1.46(1.35-1.59)$

D:J

0.63

$0.69(0.64-0.74)$

1.35 (1.16-1.58)

\section{$\mathrm{N}: \mathrm{I}$}

0.64

$0.55(0.52-0.62)$

O:I

0.59

0.52

$0.49(0.42-0.53)$

$\begin{array}{ll}\text { D:P } & \mathrm{D}: \mathrm{O} \\ 1.21 & 0.96 \\ 1.32(1.25-1.48) & 1.16(0.99-1.28) \\ 1.33(1.20-1.48) & 1.12(0.94-1.23) \\ & \\ \text { D:P } & \text { D:M } \\ 1.31 & 1.06 \\ 1.16(1.03-1.21) & 1.06(1.04-1.24) \\ 1.01(0.79-1.36) & 1.14(0.99-1.44) \\ & \\ \text { D:P } & \text { P:I } \\ 0.97 & 0.65 \\ 1.15(1.02-1.19) & 0.56(0.51-0.60)\end{array}$

D:O

1.14

1.30

$1.38(1.16-1.66)$

Both R. sherardii and R. villosa have only B alleles at this locus, and their progeny were therefore not investigated.

Locus RhM405

R. sherardii

R. $s . \times v ., \mathrm{S}^{* 1}$
AABBB

AA $A \mathbf{B B}$
B:A

1.33

$0.64(0.58-0.69)$ 
150

\begin{tabular}{lll}
$R . v i l l o s a$ & & B:A \\
$R . v . \times$ s., A & AAAA & - \\
$R . v . \times$ s., S & AAAA & - \\
\hline & AAB & $0.36(0.31-0.49)$
\end{tabular}

Both R. dumalis and R. rubiginosa have the $\mathrm{A}$ and $\mathrm{B}$ alleles at this locus, and their progeny were therefore not investigated.

$\begin{array}{llll}\text { Locus RhP507 } & & \text { G:A } & \text { I:A } \\ R . d u m a l i s & \text { AAGGI } & 0.23 & 0.50 \\ R . d . \times r ., \text { A } & \text { AAGGI } & 0.11(0-0.18) & 0.63(0.54-0.77) \\ R . d . \times r ., \text { S } & \text { AAAGI } & 0.05(0.04-0.06) & 0.59(0.53-0.63) \\ & & \text { G:A } & \\ \begin{array}{l}R . r u b i g i n o s a \\ R . r . \times d ., \text { A }\end{array} & \text { AAAAA } & - & \\ R . r . \times d ., \text { S } & \text { AAAAA } & - & \\ & \text { AAAAG } & 0.06(0.04-0.08) & \end{array}$

The G allele peak is very small and allelic ratios therefore very tentative for this locus. Both R. sherardii and R. villosa have the A and E (and probably also G but very faint) alleles in this locus, and their progeny were therefore not investigated.

\begin{tabular}{|c|c|c|c|c|c|}
\hline Locus RhP518 & & $B: C$ & $\mathrm{D}: \mathrm{C}$ & $\mathrm{F}: \mathrm{C}$ & \\
\hline R. dumalis & BCCDF & 0.62 & 0.55 & 0.55 & \\
\hline R. $d . \times r ., \mathrm{A}$ & BCCDF & $0.60(0.40-0.78)$ & $0.58(0.48-0.72)$ & $0.72(0.54-0.84)$ & \\
\hline R. $d . \times r ., \mathrm{S}$ & BCCDF & $0.64(0.39-0.75)$ & $0.55(0.39-0.67)$ & $0.71(0.57-0.79)$ & \\
\hline $\begin{array}{l}\text { R. rubiginosa } \\
\text { R. r. } \times d ., \mathrm{A} \\
\text { R. } r . \times d ., \mathrm{S}\end{array}$ & $\begin{array}{l}\text { BBCCC } \\
\text { BBCCC } \\
\text { BBCCC }\end{array}$ & $\begin{array}{l}\mathrm{B}: \mathrm{C} \\
0.94 \\
0.95(0.91-0.98) \\
0.93(0.90-0.99)\end{array}$ & & & \\
\hline $\begin{array}{l}\text { R. sherardii } \\
\text { R. s. } \times \text { v., } \mathrm{S}\end{array}$ & $\begin{array}{l}\mathbf{B C C D F} \\
\mathbf{B C C D F}\end{array}$ & $\begin{array}{l}\text { B:C } \\
0.64 \\
0.52(0.42-0.69)\end{array}$ & $\begin{array}{l}\text { D:C } \\
0.74 \\
0.64(0.56-0.76)\end{array}$ & $\begin{array}{l}\mathrm{F}: \mathrm{C} \\
0.67 \\
0.57(0.47-0.75)\end{array}$ & \\
\hline $\begin{array}{l}\text { R. villosa } \\
\text { R. v. } \times \text { s., } \mathrm{A} \\
\text { R. v. } \times \text { s., } \mathrm{S}\end{array}$ & $\begin{array}{l}\text { CCDF } \\
\text { CCDF } \\
\text { CCDF }\end{array}$ & & $\begin{array}{l}\text { D:C } \\
0.79 \\
0.56 \\
0.67(0.50-0.75)\end{array}$ & $\begin{array}{l}F: C \\
0.73 \\
0.50 \\
0.60(0.47-0.69)\end{array}$ & \\
\hline $\begin{array}{l}\text { Locus RhP519 } \\
\text { R. dumalis } \\
\text { R. } d . \times r ., \mathrm{A} \\
\text { R. } d . \times r ., \mathrm{S} \\
\text { R. } d . \times r ., \mathrm{S}_{158}\end{array}$ & $\begin{array}{l}\text { CCFGJ } \\
\text { CCFGJ } \\
\text { CFGGJ } \\
\text { CCFGJ }\end{array}$ & $\begin{array}{l}\text { C:F } \\
0.75 \\
0.85(0.39-1.37) \\
0.45(0.25-0.52) \\
0.41\end{array}$ & $\begin{array}{l}\mathrm{C}: \mathrm{G} \\
1.61 \\
1.65(0.82-2.46) \\
0.46(0.27-0.53) \\
0.85\end{array}$ & $\begin{array}{l}\text { G:F } \\
0.47 \\
0.51(0.44-0.56) \\
0.96(0.93-0.99) \\
0.48\end{array}$ & $\begin{array}{l}\text { C:J } \\
2.24 \\
2.11(1.15-3.18) \\
1.06(0.67-1.21) \\
2.06\end{array}$ \\
\hline $\begin{array}{l}\text { R. rubiginosa } \\
\text { R. } r . \times d ., \mathrm{A} \\
\text { R. } r . \times d ., \mathrm{S}\end{array}$ & $\begin{array}{l}\text { FFGGG } \\
\text { FFGGG } \\
C F F G G\end{array}$ & $\begin{array}{l}\text { C:F } \\
- \\
- \\
0.24(0.23-0.26)\end{array}$ & $\begin{array}{l}C: G \\
- \\
- \\
0.52(0.45-0.56)\end{array}$ & $\begin{array}{l}\text { G:F } \\
0.76 \\
0.69(0.64-0.72) \\
0.47(0.44-0.53)\end{array}$ & \\
\hline
\end{tabular}

Both R. sherardii and R. villosa have the G, F and J alleles at this locus, their progeny were therefore not investigated. 